\title{
RORTY ON HERMENEUTICAL INJUSTICE, LIBERAL REDESCRIPTION AND UTOPIAN IMAGINATION
}

\section{RORTY, SOBRE LA INJUSTICIA HERMENEÚTICA, LA REDESCRIPCIÓN LIBERAL Y LA IMAGINACIÓN UTÓPICA}

\author{
Federico Penelas* \\ Universidad de Buenos Aires/Universidad Nacional de Mar del Plata/ \\ CONICET
}

\begin{abstract}
Aвstract: My purpose is to use Miranda Frickers' concepts of "testimonial injustice" and "hermeneutical injustice" to draw a distinction between the policy of tolerance and the policy of solidarity in Rortyan liberalism. I shall focus on the policy of solidarity interpreted as unfolding in two phases of the imagination: the phase of critical imagination and the phase of utopian imagination. I hold that critical imagination may be understood as focusing on overcoming hermeneutical injustice through what I term liberal redescription. Lastly, I critique the Rortyan project regarding what I view as an inadequate inclination to restrict critical imagination on the basis of adopting a criterion that focuses on flaws in the development of utopian imagination and that collides with the claim to overcome hermeneutical injustice.
\end{abstract}

KeYwords: Hermeneutical Injustice, Liberal Redescription, Critical Imagination, Utopian Imagination, Marxism.

*Profesor Adjunto "Filosofía del Lenguaje" (UBA), Profesor Titular Filosofía del Lenguaje (UNMdP), Investigador CONICET. Av Corrientes 3284, 1 B (1193), fpenelas@hotmail. com. Proyecto de Investigación "Paradojas semánticas y epistémicas: conocimiento grupal, autorreferencia e inferencialismo”, PIP 11220150100807 CO, CONICET. 
Resumen: Mi propósito es utilizar los conceptos, propuestos por de Miranda Fricker, de "injusticia testimonial" e "injusticia hermenéutica” para establecer una distinción entre la política de tolerancia y la política de solidaridad en el liberalismo rortiano. Me centraré en la política de solidaridad interpretada como desplegándose en dos fases de la imaginación: la fase de la imaginación crítica y la de la imaginación utópica. Defiendo que la imaginación crítica puede ser entendida como enfocada en superar la injusticia hermenéutica a través de lo que denomino redescripción liberal. Por último, critico el proyecto rortiano a partir de diagnosticar una tendencia inadecuada a restringir la imaginación crítica sobre la base de adoptar un criterio que se centra en supuestas fallas en el desarrollo de la imaginación utópica, y que choca con la pretensión de superar la injusticia hermenéutica

Palabras clave: Injusticia hermenéutica, Redescripción liberal, Imaginación crítica, Imaginación utópica, Marxismo.

\section{Introduction}

Contingency of language is the formula that sums up Rorty's view of the way we get along in the world. He echoes Davidson's words: "we have erased the boundary between knowledge of a language and knowledge of our walk along the world in general" (Davidson, 1986: 445-46). That formula, in accordance with the idea that the self is nothing but a de-centred network of beliefs and desires (an idea which, in turn, is resumed in the formula that refers to the "contingency of the selfhood"), is a direct result of the antirepresentationalist move proposed by Rorty. In order to arrive from this antirepresentationalism to the third formula at stake, that of the contingency of a liberal community, Rorty appeals to the well-known concept of ethnocentrism.

According to Rorty, the antirepresentationalist starting point leads to the ethnocentric conclusion that: "no description of how things are from a God'seye point of view, no skyhook provided by some contemporary or yet-to-bedeveloped science, is going to free us from the contingency of having been acculturated as we were"(Rorty, 1991a: 13). Rorty uses this conclusion to state a fact and to make an assessment.

The fact that Rorty extracts from the inevitability of ethnocentrism, of proving that the only fruitful way that humans have of making sense of life is "telling the story of their contribution to a community" (Ibid., 21), is that we cannot 
but be loyal to the socio-political, democratic and liberal context in which we were acculturated. In Rorty's view, it is not about a transcendental deduction of democratic politics from antirepresentationalist premises; rather, it is a warning for all those who decide to show themselves as outsiders and who, to showcase their laterality, appeal to contact specific non-human realities, both transhistorical and extra cultural.

Dogmatism -the inability to allow one's doxastic assumptions to be challenged- is the main issue of ethnocentrism. The only way of steering away from the ethnos in which we were acculturated is through contact with unfamiliar ideas. It is at this point when Rorty assesses democratic and liberal culture. To him,

[it] has found a strategy for avoiding the disadvantage of ethnocentrism. This is to be open to encounters with other actual and possible cultures, and to make this openness central to its self-image. This culture is an ethnos which prides itself on its suspicion of ethnocentrism - on its ability to increase the freedom and openness of encounters, rather than on its possession of truth. (Ibid.: 2)

Consequently, being loyal to the culture of liberalism means being loyal to the idea that it is not suitable to remain fixed to the same acculturation process if this converges in unwillingness to maintain encounters of genuine communication with representatives of different cultures. Barry Allen has appropriately pointed out that Rorty teaches us that ethnocentrism is upheld by liberalism itself. Allen says

Our ethnocentrism is different from everybody else's. When we are ethnocentric, we are not ethnocentric. When we are true to our traditions, we are open to other traditions, when we are interested in ourselves, we are interested in what is new and different, happy (at our best) to accommodate and learn from it. (Allen, 2000: 224)

It is clear, then, that there is a strong link between Rorty's epistemological stance and his political one, thus showing himself as a faithful example of the 
liberal antirepresentationalist tradition launched by Dewey. Faced with the dogmatic danger entailed by ethnocentrism, one should say that such danger doesn't exist since it is dissolved by the liberal ethnos (although the openness to other communities imposed on us by such ethnos shouldn't give way to the idea that we see ourselves with the need to be universal interlocutors). ${ }^{1}$ As to the assertion that ethnocentrism becomes innocuous in a liberal culture, I believe that Rorty might also ask rhetorically: could anyone other than a liberal be genuinely both contextualist and ethnocentrist? So, from antirepresentationalism, which engages us with the acknowledgment of several languages as several ways of walking the world, we arrive at ethnocentrism, which implies a certain fixation to the vocabulary of a specific community. From there we come to liberalism, which conciliates us with the spirit of tolerance. ${ }^{2}$

On the other hand, by the end of Contingency, Irony and Solidarity, Rorty unfolds another way in which the risk of cultural immobility that comes with ethnocentrism can be overcome through liberalism. This overcoming does not focus on the idea of tolerance, but rather, through its characterization of the notion of moral progress, on the concept of solidarity. Rorty's idea (taken from Sellars) is to understand moral obligation using the notion of "we-intentions" as the starting point, to consider that in this field the crucial explanatory term is "one of us", as opposed to a specific "them". Rorty denies that the expression "one of us human beings" (as opposed to animals, vegetables or machines) is stronger than, for example, the expression "we, Latin-Americans" (as opposed to Americans, Europeans, etc.). The strength of "us" resides in its capacity of being opposed to a "them" that is also made up of human beings: the wrong species

1 See (Rorty, 2000a) and (Rorty, 2000b).

2 It is important to insist that it is not a deduction from liberal politics based on the assumption of antirepresentationalism. In Rorty's opinion, liberal democracy, "although it may need philosophical articulation, it does not need philosophical back up". And he adds, "on this view, the philosopher of liberal democracy may wish to develop a theory of the human self that comports with the institutions he or she admires. But such a philosopher is not thereby justifying these institutions by reference to more fundamental premises, but the reverse: he or she is putting politics first and tailoring a philosophy to suit" (Rorty, Objectivity, 178). This inversion in the order of priorities backs the sole justification that pragmatism may put forward before other philosophical theses; i.e., a pragmatic justification: the fact that it is a more useful description. For what is it more useful? For liberal democratic politics, notes Rorty. Such usefulness is based on a weak connection between pragmatism and liberalism insofar as, according to Rorty, "both are expressions of, and reinforce, the same sort of suspicion of religion and metaphysics" and "both can be traced back to some of the same historical causes (religious tolerance, constitutional democracy, Darwin)" (Rorty, 1996: 73-74). 
of human beings. To appeal to a more restricted "us" than that of "us, human beings" is to succeed in terms of moral and political persuasion, strengthening the feeling of solidarity.

Rorty is fully aware that this stance may carry with it the already mentioned undesirable trait of ethnocentrism, that is, the trait that leads a culture to close upon itself. Such danger can be avoided, according to Rorty, once again, by developing the culture of which we feel inheritors, that is, liberal democratic Western cultures. A culture that, precisely, has developed the lexicon of solidarity. Therefore, the aim is to reconcile what has been said about the idea of "us", with the exhortation that we extend our sense of "us" to the people we used to consider as "them".

This exhortation connects with Rorty's definition of a liberal as someone for whom cruelty is the worst thing that can be done. ${ }^{3}$ In fact, Rorty accounts for a sense of moral progress in the direction of greater human solidarity, although such solidarity cannot consist of the recognition of an essence present in all human beings, but should be conceived as "the capacity to perceive each time more clearly that the differences of tradition (tribal, religion, race, customs, and such) have no importance when compared to the similarities that refer to pain and humiliation" (Rorty, 1989: 192). Broadening the extension of "us" means, then, seeing "them" as part of "us, those capable of feeling pain and humiliation." We must sharpen our imagination in order to notice formerly unperceived varieties of pain and humiliation. ${ }^{4}$

Consequently, we see that the risk of dogmatism or of cultural stagnation is gone if those two liberal features highlighted by Rorty are unfolded: tolerance and solidarity. I am interested in distinguishing them at this point, because, although they are connected, they entail different conceptual and intersubjective procedures. In the first case - the practice of tolerance- it is about being open to

\footnotetext{
3 Ramón del Castillo has pointed out that this definition of "liberal" allows Rorty to present in another way the way in which liberalism implies the overcoming of the possible monadism of ethnocentrism. In his words: "There is no neutral, non-circular way of defending the claim that cruelty is the worst thing we can do and that we have an obligation to avoid it. This statement is made using the lexicon with which people in certain provinces of the world are socialized, but it is a lexicon that - as Rorty says - serves to distrust provincialism” (Del Castillo, 2015: 97).

4 See (Penelas, 2014) for a presentation of Rorty's project as a form of agonism along with a critique of certain paradoxes that the focus on humiliation can generate.
} 
the voice of others; whereas in the second, it is about expanding our conceptual resources in order to eliminate cruelty.

I believe that a good way of separating these two liberal tasks is to associate them to Miranda Fricker's treatment of two types of what she calls Epistemic Injustice. That is, cases where we can detect "a wrong done to someone specifically in their capacity as a knower" (Fricker, 2007: 1). According to Fricker, there are two basic ways in which this kind of injustice can thrive: testimonial injustice and hermeneutical injustice. In her own words:

Testimonial injustice occurs when prejudice causes a hearer to give a deflated level of credibility to a speaker's word; hermeneutical injustice occurs at a prior stage, when a gap in collective interpretive resources puts someone at an unfair disadvantage when it comes to making sense of their social experiences. An example of the first might be that the police do not believe you because you are black; an example of the second might be that you suffer sexual harassment in a culture that still lacks that critical concept. We might say that testimonial injustice is caused by prejudice in the economy of credibility; and that hermeneutical injustice is caused by structural prejudice in the economy of collective hermeneutical resources (Ibid.).

Given these definitions, it is clear to me that what we showed further up as a policy of tolerance, that is, the kind of openness to other voices that Rorty highlights as a liberal way of overcoming ethnocentric closure, may also be presented in terms of the practice of overcoming testimonial injustice. ${ }^{5}$ On the other hand, the policy of solidarity, that is, the liberal practice of increasing our empathy through considering forms of cruelty not previously conceptualized,

5 Christopher Voparil has questioned the Rortyan conception of cultural politics by presenting a series of limitations among which he emphasizes that this conception is not entirely capable of capturing the idea that "we must be open to joining the conversations of others rather than asking them to join ours ". According to Voparil, "Rorty's political vision of a global liberal utopia seeks to subsume everyone under a grand 'we' ", a "we" modeled with the vocabulary of the intellectuals of the social-democratic democracies of the West (Voparil, 2011: 125). Similar considerations can be found in other texts, although they usually emphasize the commitment attributed to Rorty to the idea of the imposition of our own "we" to others (e.g. Janack, 1998). If these criticisms were acceptable, we would be faced with a strong objection according to which the policy of Rortyan tolerance is unable for creating the conditions for testimonial justice. For a defense of Rorty from such criticisms see, for example, (Hollinger, 1993) and (Baruchello \& Weber, 2014). 
is easily describable within the range of practices that contest hermeneutical injustice. Needless to say, the policy of tolerance is intimately connected to that of solidarity. Very often, de-articulation of deafness as regards a given individual or collective who voice their experience in the public arena is achieved through dismantling prejudices based on forms of cruelty not previously perceived. This does not rule out, though, that we may mark the difference between those two practices and relate them, respectively, to policies aimed at overcoming testimonial injustice and hermeneutical injustice.

I will focus on Fricker's characterization of this latter form of epistemic injustice, because I believe her description of the way in which hermeneutical injustice is overcome is very similar to the kind of considerations made by Rorty when he thinks that social transformation requires a phase of re-elaboration of our own appreciation of certain practices from the perspective of cruelty. ${ }^{6}$

\section{Hermeneutical Injustice and Liberal Redescription}

Fricker narrows her definition of hermeneutical injustice in the following terms: "the injustice of having some significant area of one's social experience obscured from collective understanding owing to a structural identity prejudice in the collective hermeneutical resource" (Ibid.: 155). Consequently, overcoming hermeneutical injustice requires the collective consolidation of an epistemic and/ or moral virtue, the virtue of having developed an "alertness or sensitivity to the possibility that the difficulty one's interlocutor is having as she tries to render something communicatively intelligible is due not to its being nonsensical or her being a fool but rather to some sort of gap in the collective hermeneutical resources" (Ibid.: 169); virtue that does not suffice, however, given that, as Fricker rightly warns, "hermeneutical marginalization is first and foremost the product of unequal relations of social power more generally, and as such is not the sort of thing that could itself be eradicated by what we do as virtuous hearers alone" (Ibid.: 174).

\footnotetext{
6 An objection to the proposal developed in this paper could be based on the fact that Fricker herself has questioned the possibility of giving rise to the idea of epistemic injustice from ethnocentric positions such as Rorty's ones (Fricker, 2017: 54-55). See (Dieleman, 2017) for, in my opinion, an appropriate reply to that type of suspicion.
} 
Having said that, besides the virtuous alert attitude described by Fricker, what is ultimately required in order to overcome the experience of being unable -be it in the first or third person position- to conceptualize certain areas of experience, is the acquisition of the necessary linguistic-narrative resources to generate the concepts that result in a productive interpretation of the situation experienced. Fricker's example is the epistemic, moral and political leap produced by the irruption of the notion of "sexual harassment" (in reference to the Carmita Wood case $)^{7}$ as the words to name what used to be nameless and, consequently, could not even be experienced in its full victimizing dimension.

Fricker's considerations around hermeneutical injustice are, to my judgment, exactly the ones that Rorty pointed out since Contingency, Irony and Solidarity. Indeed, according to Rorty, the process of political change, within the "unavoidable obligation of reducing cruelty" that concerns every liberal, has to be preceded by an act of imagination that allows us to perceive acts of cruelty which only met blindness before or, simply, for which normal discourse had no words. Thus, the practice of redescription becomes an instrument of social transformation. Building a language able to formulate previously untold redescriptions, where cruelty can be seen where it used to be unimaginable, is something that has public consequences. If the ironist attitude of the strong poet is the one that trains us in the redescriptive task, there is a passage from private ironism to public life, since redescription is capable of generating the conditions for denouncing heretofore un-conceptualized cruelty. ${ }^{8}$

I believe that two kinds of redescriptive practices can be distinguished according to the purposes they pursue:

Ironist redescription: seeking to renovate the terms that matter in the private forum. Liberal redescription: seeking to modify the extent of application of the term "cruelty". ${ }^{9}$

\footnotetext{
Wood gave in her resignation to a post at Cornell University because of the unending sexual attention she was subjected to by one of the officials and after the University refused to transfer her far away from him. She was also denied unemployment insurance because the University alleged that her renunciation was due to personal reasons. The concept of "sexual harassment" appeared all through the demand presented by Wood against Cornell University. 8 For a detailed analysis of the political role of the idea of "redescription" in Rorty's work, see, among other texts, (Voparil, 2006: 37-54) and (Calder, 2007).

9 I gave a detailed justification of this distinction in "The Cruelty of Irony". I presented that text in the International Conference "After Irony: Discourse, Forms of Life and Politics",
} 
My point here is that the practice of liberal redescription allows to overcome situations of hermeneutical injustice. The connection between what is exposed by Fricker and Rorty can be deployed if we pay attention to the opinion of the author of Epistemic Injustice about the rise and reach of hermeneutical injustice:

hermeneutical injustice, whether incidental or systematic, involves no culprit. No agent perpetrates hermeneutical injustice-it is a purely structural notion. The background condition for hermeneutical injustice is the subject's hermeneutical marginalization. But the moment of hermeneutical injustice comes only when the background condition is realized in a more or less doomed attempt on the part of the subject to render an experience intelligible, either to herself or to an interlocutor. The hermeneutical inequality that exists, dormant, in a situation of hermeneutical marginalization erupts in injustice only when some actual attempt at intelligibility is handicapped by it (Ibid: : 159).

It is in this instance of indetermination of the intelligibility of experience where the need for redescriptive liberal practice breaks in: the practice that, from metaphorical imagination, seeks to crystallize new material inferences in which the expression "cruelty" is involved. At this point, it is relevant to clarify that, even under the definition of liberal redescription in terms of "extent for the application of the term 'cruelty", this does not mean that it might not generate conceptual changes. If one were to adhere to an inferentialist semantics like that acknowledged by Rorty through Brandom, the change based on the extensional application of a word would produce, at the end of the day, a genuine conceptual transformation. ${ }^{10}$ It is possible to defend the idea that there is a reflexive equilibrium in the practice of extending the application of a word, because this practice could be described in the following terms: first, one begins with certain paradigms of the use of the term "cruelty" ("paradigms" in the sense of certain examples of applications of the term which are used as canonical, evaluating their similarity in order to accept or reject other applications); second, one experiments with a novel application; finally, one connects it to the previous para-

which was organized by Ramón del Castillo at UNED, Madrid, 2015. The article remains unpublished.

10 See (Brandom, 2000: chapter 1). 
digms. This practice can, and often does, generate a process in which paradigms are modified, ${ }^{11}$ as in the case of Carmita Wood, where it was possible to go from "flirting" to "cruelty" through the incorporation of "sexual harassment" to the standing inferential practices.

Rorty assumes that such passage usually implies a stage of deep conceptual experimentation, even of pure nonsense. Here he echoes the words of Marilyn Frye when she describes her own writing as "a sort of flirtation with meaninglessness - dancing about a region of cognitive gaps and negative semantic spaces, kept aloft only by the rhythm and momentum of my own motion, trying to plumb abysses which are generally agreed not to exist" (Frye, 1983: 154). Therefore, in Rorty's words:

There is no method or procedure to be followed except courageous and imaginative experimentation. [...] [M] eaninglessness is exactly what you have to flirt with when you are in between social, and in particular linguistic, practices - unwilling to take part in an old one but not yet having succeeded in creating a new one. [...] Drop the appeal to neutral criteria [...]. Instead, just make invidious comparisons between the actual present and a possible, if inchoate, future (Rorty, 1998: 217).

Now, besides this condition prior to political change, consisting in the imagination being alert to new ways of cruelty, the same transformation in the public field is cut across by another phase of the imagination. In Rorty's view, when it comes to criticizing the practices and language of the community one belongs to, such criticism "can only take the form of imagining a community whose linguistic and other practices are different from our own, $[\ldots]$ once one sees the need for something more than an appeal to rational acceptability by the standards of the existing community, then such an act of imagination is the only recourse" (Ibid.: 214). Rorty's idea, stemming from his antirepresentationalism, is to differentiate radicalism from utopianism, with the intention of defending the adoption of the latter and not the former:

11 See (Penelas, 2012). 
Radicals think that there is a basic mistake being made, a mistake deep down at the roots. They think that deep thinking is required to get down to this deep level, and that only there, when all the superstructural appearances have been undercut, can things be seen as they really are. Utopians, however, do not think in terms of mistakes or of depth. They abandon the contrast between superficial appearance and deep reality in favor of the contrast between a painful present and a possibly less painful, dimly seen future (Ibid.).

Radicalism seems useless to Rorty for political transformation, at least if it is not accompanied by the utopian moment that consists in imagining alternatives. Uncompromising radicalism can lead to the desire for "total revolution", which consists in expecting "some" revolution, without engaging in any concrete alternative of change and, hence, inadequate as a motor for action, a severe sin for a pragmatist. ${ }^{12}$

We notice, then, that the road to political and social transformation is understood, by way of Rortyan liberalism, as the sum of two different applications of the imagination. Let us call the first one "critical imagination": it serves, via the liberal redescription device, to perceive new ways of cruelty that permit

12 The utopian/radical distinction should not be confused with the reform/revolution distinction. The first refers to the presence or absence of viable alternatives to the status quo, the second refers to the possibility or not of escaping violence for political and social transformation. Rorty has pointed out on several occasions that he does not impugn revolutionary politics per se. In 1990 he wrote: "This is not to say that there is any particular reason for optimism about America, or the rich North Atlantic democracies generally [...] But at the present time the United States is still a functioning democratic society - one in which change occurs, and can be hoped for, as a result of persuasion rather than force". However, that statement did not prevent him from pointing out the following: "Several of these democracies, including the United States, are presently under the control of an increasingly greedy and selfish middle class - a class which continually elects cynical demagogues willing to deprive the weak hope in order to promise tax cuts to their constituents. If this process goes on for another generation, the countries in which it happens will be barbarized. Then it becomes silly to hope for reform, and sensible to hope for revolution" (Rorty, 1991a: 15 n29). In the same sense, Rorty had already pointed out in Contingecy, Irony and Solidarity that "it is hard to imagine a diminution of cruelty in countries like South Africa, Paraguay and Albania without violent revolution" (Rorty, 1989: 63 n21). As Giorgio Baruchello and Ralph Weber have pointed out in relation to Rorty's reformist commitment, we must keep in mind that "he has historicized his own position, giving it the status of a suggestion, an argument $\mathrm{f}$ shorts, underlining that it is too contingent as much as anything else" (Baruchello \& Weber, 2014: 209). 
to overcome the different displays of hermeneutical injustice. The second one, let us call it "utopian imagination", arises from the need to overcome the conditions that enable the actions of perceived cruelty. It advances by imaginatively developing alternative and feasible communities in which those conditions do not apply.

The role played by the notion of cruelty in this process is crucial. Liberals, as defined by Rorty, cannot forswear the will to perceive kinds of cruelty previously unnoticed and, thus, must be cautious and predisposed to any redescription that may shed some light on cruelty in unpredicted areas. Consequently, she must open her imagination so that cruelty doesn't pass her by. On the other hand, once those inferential practices produced by redescription are accepted and experienced, she must embark on the utopian adventure. Resignation to what is given is the temptation that must be avoided. In any case, unconcerned liberals because of lack of imagination are those who have not experienced the moment of critical imagination or have not given enough credit to the redescriptions brought about by such moment. Once cruelty has been illuminated, the lack of imagined alternatives cannot be experienced as anything but a burden.

\section{The Articulation of Critical and Utopian Imagination}

An issue that merits special attention in the Rortyan proposal is that, given his critique of radicalism, there is a tension in his work between, on the one hand, the account of the moment when liberal redescription develops as a stage marked by indeterminate experimentation and, on the other, his presentation of the second moment of imagination, the utopian moment, as a criterion of legitimation of the redescriptions to be considered. To see this, let us pay attention to the way Rorty unfolds his criticism of Marxism.

Rorty's critique of Marxism aims to place it within the spectrum of unmasking metaphysical philosophy, that is, the philosophical strategy that intends to account for certain hidden realities behind immediate appearances, which dates back to Plato. The antirepresentationalist turn is its antithesis. I shall not discuss the relevance of this criticism. I will simply question whether this critique suffices, from a Rortyan pragmatist point of view, to get rid of all Marx and Marxism have striven to highlight. Indeed, as Rorty rightly says, "the metaphysician also redescribes, even when he does it in the name of reason and not in the name 
of imagination" (Rorty, 1989: 90). To accuse someone of being "metaphysical" only means, "you also redescribe imaginatively", but it is not enough if what we want to say is "your redescription is useless".

What I am trying to get at is to point out a way to understand the meaning of Bernard Shaw's following consideration: "Das Kapital is one of those books that would change people's minds if they could be persuaded to read it" (Shaw, 1993: 340). I believe that, other than saying that every reader of Capital would understand and feel comfortable inside the difficult passageways of Marxist theory, what the quotation states is that those who read the book might start seeing the capitalist production system as intrinsically cruel, beyond the issue of fairness or unfairness of salaries. They would mention the fact that the book allowed them to redescribe certain practices in terms of cruelty. My idea is that Capital can be counted among those books that have shown us who are the ones that suffer (Rorty's examples of that kind of books include: The Making of the English Working Class, Uncle Tom's Cabin, Discipline and Punish, 1984, etc.). It is worth remembering that Rorty made a similar move, ten years after the fall of the Wall, when he vindicated The Communist Manifesto in his essay "Failed Promises, Glorious Hopes". ${ }^{13}$

Wondering why Rorty not only does not mention Capital but also voices misgivings about the relevance of reading it, ${ }^{14}$ is tantamount to asking why he does not admit or even contemplate the possibility of considering the phenomenon of surplus value as an expression of cruelty. It is obvious that the omission cannot be based on the assessment that such a phenomenon is not something real, given the antirepresentationalist standpoint Rorty comes from. Neither can he, in view of his pragmatism, account for its omission saying that it is a useless redescription, because its utility can only be measured by its efficacy in changing our perspective on certain practices. Efficacy which was proved by the immeasurable amount of people and communities that have "changed their minds" by apprehending such redescription. Rejecting the obstacles of Marxist theory, with the goal of avoiding any possible metaphysical outlines it may have, and only preserving the fact that Marx has widened our imagination by giving us the metaphors/tools necessary to realize certain redescriptions in terms of cruelty allows us to abandon the

13 See (Rorty, 1999: 201-9).

14 See (Rorty, 1999: 210-22). 
idea that the omission at stake is a consequence of assuming an anti-essentialist antrepresentationalism.

So, let us pay close attention to the following statements made by Rorty: ${ }^{15}$

Left wing intellectuals will need time to make the psychoanalytic and terminological readjustment that may allow them to conceive that there is no alternative to capitalism. The left will have to learn to be more modest: in the present day, nobody proposes anything better than market economy (Uzan, 1992: 5).

I understand that the failure of socialism suggests that world economies will always be market economies, or, at least, should always be market economies; that a substitute for private property does not exist (Pomeraniec and Tabarovsky, 1996: 2).

How does Rorty account for these statements? For the sake of consistency, he cannot base the absence of alternatives on anything other than the lack of utopian imagination. In his discussion with Nancy Fraser, one of his left-wing feminist critics, he points out:

She sees, and I do not see, attractive alternatives (more or less Marxist in shape) to such institutions as private ownership of the means of production and constitutional democracy, attractive alternatives to the traditional social democratic project of constructing an egalitarian welfare state within the context of these two basic institutions. I am not sure whether our differences are due to Fraser's antifoundationalist theory hope or to my own lack of imagination (Rorty, 1998: 209 n.15).

15 There are numerous quotes with similar contents in Rortyan works but I have chosen to select these two examples because Rorty used those words in interviews by newspapers in my country, Argentina. They were held after the fall of the Berlin Wall, at a time when my country displayed neo-liberal policies that soon led the country to the harshest financial crisis in its history, producing untold levels of poverty and inequality. 
The acknowledgment of this lack of imagination (at some point related by him to his condition as a First World citizen when he said: "if there is hope it lies in the imagination of the Third World" (Rorty, 1991b: 192)) can't take the appearance of lightness it has in his writings if it isn't traced back to some criteria that points to reject the liberal redescription that consents the inference from "salaried work" to "cruelty" through the introduction of the expression "surplus value " (analogous to the redescription that went from "flirting" to "cruelty" via "sexual harassment").

As I said, it is not my intention to focus on the Rortyan criticism of Marxism but, rather, to use it as an example to extract a general consequence for imaginative dialectics as conceived by Rorty. In fact, Rorty's strategy to leave aside the Marxist description of surplus value in terms of cruelty is to deny it any critical potential insofar as it is not coupled by market economy alternatives. Imagination of the cruel is subsumed to the imagination of the alternative: a liberal redescription will only be legitimate if it is accompanied by the delineation of feasible alternatives to the practices that such redescription has exposed as cruel. Having said this, we must not trivialise the idea of utopian imagination since it might be argued that imagining alternatives is no tiresome task (in fact, Marxism devised the communist utopia). Once we have spotted whatever we find condemnable, it is not hard to imagine a world where such factor would not be present. The trouble lies in imagining the actual steps to be taken to arrive at that world. Therefore, utopian imagination actually unfolds in two phases: imagining the ends and imagining the means. Apparently Rorty's point is that, given his adoption of the Deweyian concept of the ends-means continuum and that there are no fixed ends but, rather, ends-in-view, ${ }^{16}$ any form of utopian imagination that fails in the phase of imagining the means should be impugned. That is the idea behind the critique of radicalism and the political stress on movements instead of campaigns. The point is that Rorty does not merely question the projects that fail to articulate an adequate utopian imagination; in his view, such impugnation should serve as the basis to devaluate the relevance of the end product of the critical imagination that originated such failed utopian enterprise.

Indeed, the viability of the utopian imagination, specifically in the phase of designing the means, (which does not involve mere fixed ends, but rather, ends-in-view under the adoption of the Deweyian concept of the ends-means

16 See (Dewey, 1988). 
continuum) presents itself as a criterion for the evaluation of the legitimacy/ utility of critical imagination (the one applied in the procedure of liberal redescription). It would appear that the connection between the two types of imagination is exactly the opposite. The point seems to be that no one can imagine alternatives seen as legitimate if he has not previously perceived the intrinsic cruelty of the status quo because the legitimacy of the alternative posited will be judged according to the current standards. If such standards were not previously acknowledged as cruel, any change proposed, including the means suggested, will be assessed from within the paradigm that does not see or underrates the cruelty at stake. Acknowledging the cruelty ingrained in a system is the major anomaly that leads towards paradigmatic change in politics. An utopian proposal can only be judged feasible within the framework of such change. Consequently, the moment when cruelty is imagined always comes first in the order of legitimation, before the moment when alternatives are imagined. The latter cannot judge the former.

The other crucial problem posed by taking an utopian action plan deemed feasible as a criterion for legitimising critical imagination is that those who propose a redescription of practices in terms of cruelty, even without positing alternatives, should be stimulated because they are the condition of possibility of moral progress. This is seen more clearly if we remember that Rorty himself held that critical imagination needs to be unfolded without many bindings, hosting nonsense, assuming that metaphor is but an annoying noise that doesn't entail new meanings, which is the same as saying that a metaphor cannot be discarded qua metaphor. Rorty might point out that there are two moments: the first one, strictly metaphorical, the moment of the irruption of expressive novelty, of experimental probing, and the second one, the one of literalization of the metaphor, the latter being the one that must be governed by the restriction of the viability of utopian imagination. But I believe that even if a liberal metaphor (which generates unexpected distortions in the semantic field of "cruelty") should reach a certain level of literalization -in the sense that a given sector of society starts playing the game of the newly instituted inferences- it could be said that, even if such metaphor were unable to articulate itself into a clear and realistic utopian alternative, discarding it ipso facto would be a premature movement within the context of the economy of liberal imagination.

Rorty might insist saying that continuing with redescriptions without their respective utopian correlative is, after a while, a waste of time. Time that should be destined to utopias that can lead to the proposal of actual and viable steps 
that will allow to overcome cruelties revealed after the process of elimination of hermeneutical injustice and that, shallow as they might seem, are of no minor importance in the lives of millions of people. This Rortyan insistence has, to my judgment, but one problem: it collides with Rorty's own statements, such as the following:

Still, all that we liberal intellectuals in the States can imagine doing is building up the welfare state by e.g. passing a national health insurance law, starting an employment program for the ghetto blacks, and the like. But even if all our dreams of such laws and programs were fulfilled, this would leave the underlying political problem untouched: the emergence of a global call of the superrich, a class to which only a few privileged Americans will belong, leaving the rest of the American electorate to experience an economic insecurity which endangers democratic consensus (Rorty, 1997: 287).

This Rortyan acknowledgment of the unfeasibility of the social-democrat utopia, let alone the communist/socialist one, should be understood, in order to be consistent, as a condemnation of any attempt of critical imagination to devise Rorty's greatest, no-time-waster, obsession throughout his life: to build a liberal redescription of economic inequality as inherently cruel. If such acknowledgment were challenged, even assuming pessimism as regards the future, then Rortyan liberalism should be more generous when it comes to evaluate the activism of those who find their support in the exercise of critical imagination and cannot offer but a babble of utopian imagination.

However, I believe that the deficiency of Planning Criterium to demarcate the scope of the legitimacy of liberal redescriptions is only fully dimensioned once it is noticed what was said above, that is, that the effective exercise of critical imagination must be conceptually assimilated to the task of overcoming hermeneutical injustice. In this way, such assimilation should not be evaluated merely as a correlation of Rorty's work with Fricker's inshigt; on the contrary, this correlation sheds light on certain limitations of Rortyan meliorism.

Indeed, the presentation of Rortyan conception of moral and political progress in terms of two moments, that of the critical imagination and that of the utopian imagination -and the understanding of the first one in consonance 
with the identification and overcoming of a stage in which a certain hermeneutic injustice governs- allows us to realize something of importance: that the result of the exercise of liberal redescription -which involves the passage to the discursive circulation of a new concept- cannot be turned back without a return to the situation of precedent injustice. The greatest teaching of Fricker, by allowing us to observe a type of injustice of a specifically epistemic nature that involves testimonial discrimination or lack of certain concepts, is that an impoverishment of our linguistic baggage can be in itself a form of subjection. The demand to put aside the circulation of certain concepts that were coined and that persist in their capacity to allow the enunciation of an experience of harm requires firstly pointing out that this conceptual cut does not imply a regression towards a situation of hermeneutical injustice. I do not deny that it is possible to make a call like that in certain circumstances; still what I think is that it seems excessive to defend the idea that the mere fact that we cannot imagine concrete ways in which we could arrive in a community where it is not present the type of non hermeneutical injustice that the coined concept allows us to enunciate is sufficient to claim that the suppression of that concept in our dialogical exchanges does not suppose a return to a situation where an injury is experienced but in an ineffable way which gives rise to a hermeneutical submission. Failure of our utopian imagination cannot therefore be the basis for justifying that the past which was prior to the emergence of the literalized metaphor must not be described in terms of hermeneutical injustice. On the other hand, much more unacceptable is to say that this failure can justify returning to an earlier stage that we have no choice but to describe as unjust from a hermeneutical point of view. Thus, Planning Criterium, once we link the concepts of "critical imagination" and "hermeneutical injustice", becomes unviable from the point of view of a reformist proposal as intended by Rorty.

If one realizes that Epistemic Injustice was published by Fricker in the same year of Rorty's death, we can point out that the final criticism that I have developed in this article would not be fair to be thrown to the author of Contingency, Irony and Solidarity. We can say that Fricker allowed us to overcome a state of hermeneutical injustice, that in which we had no way of conceptualizing a type of damage resulting from linguistic-conceptual limitations. So, we can read Rorty as another victim of the hermeneutical deficit of our previous philosophical discursive community. What the argument developed here does allow is to question harshly the current persistence of censorship attempts of certain critical discourses that claim to be defended on the basis of some more or less sophisticated 
version of Planning Criterium. After Fricker and the discursive fertility of his new metaphors it is not possible to continue being Rortyan in the same way.

\section{Conclusions}

In this paper I set out to show the relevance of the study of epistemic injustice for an adequate articulation of the Rortyan approach to the politics of social transformation within the framework of his pragmatist liberalism. The value of the concept of hermeneutical injustice was highlighted in order to elaborate the concept of policies of solidarity that can be found in Rorty's work. The distinctions drawn between ironist redescription and liberal redescription and between critical imagination and utopian imagination allowed me to identify a tension within the Rortyan thought, which manifests itself in the difficulties to put together in his project the stimulus to metaphorical experimentation with the request to abjure of an useless radicalism. The tension in question arises from the identification of what I have called Planning Criterion. My final argument makes it possible to revalue the re-reading of Rortyan policies of solidarity in terms of hermeneutical injustice, because, once the very idea of that kind of epistemic damage is considered, the Planning Criterion becomes morally and politically inadmissible. The future bet for Rortyan liberals must be, according to this diagnosis, to be able to privilege critical imagination without losing the pragmatist perspective. 


\section{Acknowledgments}

To Christopher Voparil for his inspiration to write this paper; to Bjørn Ramberg for his comments; to the anonymous referee for the important improvement for this paper caused by her/his criticism.

\section{References}

Allen, B. (2000). "What was Epistemology?". In Robert Brandom (ed.) Rorty and His Critics. Malden/Oxford: Blackwell, 220-236.

Baruchello, G. and Weber, R. (2014). “'Who are We?' On Rorty, Rethoric and Politics", The European Legacy, 197-214.

Brandom, R. (2000). Articulating Reasons. Cambridge: Cambridge University Press.

Del Castillo, R. (2015). Rorty y el giro pragmático. Barcelona: Bonalletra Alcompas.

Dewey, J. (1988). “Theory of Valuation”. In Jo A. Boydston (ed.) The Later Works of John Dewey 1925-1953, Vol. 13. Carbondale-Edwardsville: Southern Illinois University Press, 189-251.

Davidson, D. (1986). "A Nice Derangement of Epitaphs". In Ernest Lepore (ed.) Truth and Interpretation. Perspectives on the Philosophy of Donald Davidson. Oxford: Basil Blackwell, 433-446.

Dieleman, S. (2017). "Realism, Pragmatism and Critical Social Epistemology". In Susan Dieleman, David Rondel and Christopher Voparil (eds.) Pragmatism and Justice. New York: Oxford University Press, 129-143.

Fricker, M. (2007). Epistemic Injustice Power and the Ethics of Knowing, Oxford: Oxford University Press.

— (2017). "Evolving Concepts of Epistemic Injustice“. In Ian James Kidd, José Medina and Gaile Pohlhaus Jr. (eds.) (53-60), London/New York: Routledge.

Frye, M. (1983). The Politics of Reality, Trumansburg: Crossing Press. 
Hollinger, D. (1993). "How Wide the Circle of the 'We'? American Intellectuals and the Problem of the Ethnos since World War II", The American Historical Review, Vol. 98, $\mathrm{N}^{\circ}$ 2, 317-337.

Janack, M. (1998). "Rorty on Ethnocentrism and Exclusion". Journal of Speculative Philosophy, Vol. 12, N 3, 204-216.

Penelas, F. (2012). "The Idea of Epistemic Community from the Standpoint of Rortyan Conversationalism”. Pragmatism Today, Vol. 3, N 1, 98-110.

- (2014). "Contributions and Limits of Rortyan Pragmatism for Political Agonism". Contemporary Pragmatism, Vol. 11, № 1, 103-113.

Pomeraniec, M. and Tabarovsky, D. (December 9, 1996). "La filosofía: ¿ciencia o literatura? Entrevista con Richard Rorty". Clarin/Suplemento Cultura y Nación, Buenos Aires, Argentina, 2-3.

Rorty, R. (1989). Contingency, Irony and Solidarity. New York: Cambridge University Press.

- (1991a). Objetivism, Relativism, and Truth. New York: Cambridge University Press.

- (1991b). Essays on Heidegger and Others. New York: Cambridge University Press.

- (1996). "Response to Ernesto Laclau". In Chantal Mouffe (ed.), Deconstruction and Pragmatism. Londres: Routledge, 71-78.

- (1997). "The Intellectuals and the Poor in the Contemporary United States". In Emil Višňovský and Gabriel Bianchi (eds.), Discourse-Intellectuals-Social Communication, Bratislava: Veda, 281-287.

— (1998). Truth and Progress. Cambridge: Cambridge University Press.

— (1999). Philosophy and Social Hope. London: Penguin.

- (2000a). "Universality and Truth". In Robert Brandom (ed.) Rorty and His Critics. Malden/Oxford: Blackwell, 1-30.

- (2000b). "Response to Jürgen Habermas". In Robert Brandom (ed.) Rorty and His Critics. Malden/Oxford: Blackwell, 56-64.

Shaw, G. B. (1993). "What I Owe to German Culture", in Dan H. Laurence and Daniel J. Leary (eds.) The Complete Prefaces, Vol. 1. New York: Penguin.

UzAN, M. (March 26, 1992). "Los intelectuales ya no deben negar las realidades" (interview with Richard Rorty). Clarin/Suplemento Cultura y Nación, Buenos Aires, Argentina, 4-5.

ÉNDOXA: Series Filosóficas, n. 43, 2019, pp. 313 - 333. UNED, Madrid 
Voparil, C. (2006). Richard Rorty: Politics and Vision. Lanham: Rowman and Littlefield Pub.

- (2011). "Rortyan Cultural Politics and the Problem of Speaking for Others". Contemporary Pragmatism 8.1, 115-131.

Recibido: 3/07/2017

Aceptado: 20/03/2019

Este trabajo se encuentra bajo una licencia de Creative Commons ReconocimientoNoComercial-SinObraDerivada 4.0 